\title{
Perturbacje kinematografii słoweńskiej
}

\author{
MAŠA GUŠTIN
}

Choć Słowenia nie była niepodległym państwem aż do 1991 r., już od początków istnienia kina mogła pochwalić się niewielką, ale własną produkcją: najpierw z okresu Austro-Węgier ${ }^{1}$, a następnie w czasach pierwszej Jugosławii (kiedy to w 1931 r. Janko Ravnik nakręcił pierwszy słoweński dokumentalno-fabularny film pełnometrażowy W królestwie Złotorożca /V kraljestvu Zlatoroga/). Rok później awangardysta teatralny Ferdo Delak zrealizował pierwszy fabularny film pełnometrażowy - Triglavskie stromizny (Triglavske strmine) - w konwencji bohatersko-patriotycznych niemieckich Bergfilmów. Na kolejny film przyszło Słoweńcom czekać aż 16 lat, kiedy to po II wojnie światowej narodziła się „nowa” Jugosławia i powstały struktury kinematograficzne. W przeciwieństwie do polityki Królestwa Jugosławii, socjalistyczne władze państwa, mając świadomość znaczenia filmu jako środka indoktrynacji ideologicznej czy też „kształtowania” narodu, przygotowały w 1945 r., na wzór Związku Radzieckiego ${ }^{2}$ odpowiedni program i od razu rozpoczęły budowę struktur nowej kinematografii jugosłowiańskiej w ramach Państwowego Przedsiębiorstwa Filmowego z siedzibą w Belgradzie. Przedsiębiorstwo to przejęło istniejące już kina i sprzęt, by znacjonalizować je do końca roku $1948^{3}$.

W tym powojennym okresie Komitet Centralny Związku Komunistów Jugosławii decydował o wszystkim, co dotyczyło przemysłu filmowego: co zostanie przejęte od Sowietów, a co od Amerykanów, co będzie kręcone i co Jugosłowianie będą oglądali. W tym samym czasie w sześciu republikach wchodzących w skład federacji powstały oddziały, tzw. Dyrekcje Przedsiębiorstwa Filmowego (Direkcija filmskega podjetja) $\mathrm{z}$ własnymi funduszami. Ich podstawowym zadaniem była produkcja kronik filmowych, filmów dokumentalnych i kulturalno-edukacyjnych, organizacja kin stacjonarnych i objazdowych oraz projekcji filmowych. Słoweński oddział Dyrekcji na początku angażował doświadczonych byłych właścicieli instytucji kinowych (np. właściciela Sava Film i operatora Metoda Badjurę), filmowców (np. dźwiękowca Rudiego Omotę) oraz rokujących młodych byłych partyzantów (m.in. Franca Štiglicę, Franca Kosmača, Igora Pretnara), którzy wykazywali zainteresowanie nową sztuką. Przy słoweńskim Wydziale Agitacji i Propagandy Zgromadzenia Wykonawczego Frontu Wyzwolicielskiego (Oddelek za agitacijo in propagando Izvršnega odbora Osvobodilne fronte) zaraz po wojnie powstał Wydział Fotografii i Kinematografii (Oddelek za fotografijo in kinematografijo $)^{4}$, a jego przewodniczącym został France Brenk - słoweński cineaste, pionier kinematografii, aktywista, funkcjonariusz państwowy, literat, o którym z pewną dozą humoru Marcel Štefančič Jr. napisał, że jest to najwyżej postawiony słoweński szpieg filmowy w Belgradzie po II wojnie światowej ${ }^{5}$. 
Okres socjalizmu administracyjnego (1945-1950), a przede wszystkim rok 1947, był dla słoweńskiej kinematografii przełomowy - wówczas ukazała się Ustawa o pięcioletnim planie rozwoju gospodarki narodowej Jugostawii (1947-1951) i w tym czasie zostały ustanowione fundamenty współczesnej kinematografii jugosłowiańskiej. Przykładem może tu być artykuł 17., w którym sformułowano m.in. wymóg ustanowienia instytucji dystrybucyjnych oraz studiów filmowych we wszystkich stolicach republik federacyjnych - w Lublanie był to Triglav Film (pierwszym dyrektorem został wspomniany już France Brenk) zajmujący się produkcją oraz Vesna Film odpowiedzialna za dystrybucję. Ustawa ta przedstawiła również konkretny plan produkcji, według którego centralne studio belgradzkie miało realizować 25 filmów pełnometrażowych rocznie, zaś oddziały poszczególnych republik po 5 filmów. Oprócz tego ustawa zakładała produkcję 100 filmów dokumentalnych rocznie i 125 kronik filmowych, a także kinofikację kraju, tzn. takie planowanie budowy nowych sal kinowych, by na 10000 mieszkańców przypadał przynajmniej jeden kinematograf ${ }^{6}$.

Restrukturyzacji i formowaniu struktur nowo powstałej kinematografii towarzyszyła także ogromna potrzeba stworzenia jednostek kształcenia przyszłych twórców filmowych. Założona w 1945 r. Lublańska Akademia Sztuki Aktorskiej (dziś AGRFT), stopniowo powiększała się o wydziały: filmowy, radiowy i telewizyjny, a w 1948 r. w Lublanie otwarto dwuletnią Techniczną Szkołę Filmową (Filmska tehnična šola), której absolwenci zostali zatrudnieni w Triglav Film. W tym samym roku w studiu tym powstał (na podstawie scenariusza Cirila Kosmača) pierwszy słoweński pełnometrażowy dźwiękowy film fabularny Franca Štiglica ${ }^{7} \mathrm{Na}$ własnej ziemi (Na svoji zemlji, 1948), który przyszłemu słoweńskiemu kinu partyzanckiemu nadał określony kierunek wbrew manierze socrealizmu. Tematyka wojny i rewolucji była tu ukazana z perspektywy osobistej, co pozwalało filmowi mówić o fundamentalnych sprawach egzystencjalnych oraz bezsensie wojny ${ }^{8}$. W roku 1949 Na własnej ziemi wraz z filmem Jugosłowiańskie tańce ludowe (Jugoslavenski narodni plesovi, 1948) chorwackiego reżysera Rudolfa Sremca po raz pierwszy reprezentowały film jugosłowiański w konkursie na festiwalu w Cannes ${ }^{9}$.

Po roku 1948 i konflikcie ze Związkiem Radzieckim rozpoczęły się w Jugosławii czystki, których efekty były odczuwalne w całej przestrzeni publicznej portrety Stalina zniknęły z instytucji państwowych, ,zwolennicy” frakcji radzieckiej znaleźli się w obozie na Nagiej Wyspie, w kinach natomiast na jakiś czas zaprzestano wyświetlania radzieckich filmów ${ }^{10}$, zastępując je m.in. produkcjami hollywoodzkimi. W połowie lat 50. Jugosławia zdecydowała się wypetnić swój budżet dewizami i otworzyła granice dla zachodnich turystów, co przyciągało filmowców z innych krajów. Także Triglav film, jak możemy przeczytać na stronie internetowej Viba Film, z powodu mniejszych wpływów środków finansowych ze strony państwa musiat otworzyć się na rynki zagraniczne i wspólnie z amerykańskimi i europejskimi partnerami nakręcił około 40 filmów ${ }^{11}$, takich jak Quand vient l'amour (Kiedy przychodzi miłość, reż. Maurice Cloche, 1957), Wielki błękitny szlak (La grande strada azzurra, reż. Gillo Pontecorvo, 1957) czy Marsz żałobny (L'Enclos, reż. Armand Gatti, 1961).

W latach 50. i na początku 60. pod skrzydłami Triglav Filmu powstało wiele produkcji, które odniosły sukces i dziś są uważane za klasyki filmu słoweńskiego. Do nich należą wspomniane (anty)wojenne dramaty Štiglica czy też kultowy film 
młodzieżowy z pierwszym słoweńskim superbohaterem Kekec (reż. Jože Gale, 1951), nagrodzony Złotym Lwem na festiwalu weneckim. Film ten zdobył serca młodszych i starszych widzów w całej Jugosławii i był pierwszym prawdziwym słoweńskim hitem. Sukces odniosła również komedia romantyczna Vesna (1953) Františka Čápa, reżysera o czeskich korzeniach, oraz jej kontynuacja Nie czekaj na maj (Ne čakaj na maj, 1957). Większość ówczesnych i późniejszych filmów okresu socjalizmu i państwa jugosłowiańskiego stanowiła ekranizacje literatury słoweńskiej. Wymienić tu należy Nowobogactwo (Jara gospoda, 1953) - debiut filmowy mistrza teatru Bojana Stupicy, Samorastniki (1963) Igora Petnara - nagrodzony Złotą Areną na Festiwalu Filmu Jugosłowiańskiego w Puli, czy też ekspresjonistyczą Balladę o trąbce $i$ obłoku (Balada o trobenti in oblaku, 1960) Štiglica.

W 1961 r. w wytwórni Triglav Film debiutował obrazem Taniec $w$ deszczu (Ples $v$ dežju) młody Boštjan Hladnik ${ }^{12}$, prekursor słoweńskiego filmu modernistycznego, a także Nowego Filmu Jugosłowiańskiego ${ }^{13}$. Ten egzystencjalny melodramat, w którym niedoszły malarz Peter i aktorka teatralna Maruša mierzą się z życiowymi rozterkami, gnieżdżąc się w małym wynajętym pokoiku w Lublanie, stał się swego rodzaju filmem programowym dla wszystkich pragnących zmian młodych twórców jugosłowiańskich ${ }^{14}$. Krytyczne spojrzenie na społeczeństwo socjalistyczne oraz obecność pierwszych antybohaterów to domena filmów Jože Babiča, np. Potańcówka (Veselica, 1960) czy Nie wracaj ta sama droga (Po isti poti se ne vračaj, 1965). Drugi z nich, wpisujący się w trend Nowego Filmu Jugosłowiańskiego, podejmuje problematykę losów pracowników sezonowych z innych krajów federacji i ich życia na marginesie społecznym bądź wśród gardzących nimi Słoweńców. Szczytowymi osiągnięciami nowej fali w Słowenii były egzystencjalna Historia, której nie ma (Zgodba, ki je ni, 1967), dekadencka, asocjacyjno-miłosna opowieść Na papierowych samolotach (Na papirnatih avionih, 1967) Matjaža Klopčiča ${ }^{15}$ czy też radykalnie dysydencki film Byki zamkowe (Grajski biki, 1967) Jože Pogačnika, którego głównymi bohaterami są wychowankowie poprawczaka.

W latach 60. ubiegłego wieku w strukturach kinematograficznych doszło do zmian organizacyjnych. Słoweńscy filmowcy założyli własne przedsiębiorstwo filmowe Viba Film, które w 1966 r., po ogłoszeniu przez Triglav Film upadłości ${ }^{16}$, przejęło jego studio filmowe, pomieszczenia oraz laboratorium i stało się najważniejszym słoweńskim producentem filmowym aż do roku $1991{ }^{17}$.

Ważnym momentem dla ówczesnych filmowców było powstanie w 1958 r. telewizji jugosłowiańskiej, której program wypełniały materiały ze wszystkich republik. W tym samym roku w każdej z republik zostały założone oddziały telewizji. W Słowenii była to RTV Ljubljana, która odegrała ważną rolę w historii krajowej kinematografii, bo właśnie tam zatrudnienie znaleźli liczni słoweńscy filmowcy. W latach 70. i 80. oddział ten często współpracował przy produkcjach filmowych z Viba Film.

Należy wspomnieć, że w latach 60. pod względem instytucjonalnym kinematografia słoweńska przeżywała odrodzenie: w $1963 \mathrm{r}$. w Lublanie rozpoczęła działalność Kinoteka pod auspicjami Kinoteki Jugosłowiańskiej (1949), od 1962 r. zaczął się ukazywać magazyn filmowy „Ekran”, przy Akademii Sztuki Aktorskiej otwarto Wydział Reżyserii Filmowej i Telewizyjnej, a w 1968 r. utworzono Słoweńskie Archiwum Filmowe, które pod kierownictwem Ivana Nemaniča zaczęło 
kolekcjonować, ewidencjonować i naukowo opracowywać archiwalne materiały filmowe, do tego czasu nierzadko przetrzymywane w niezabezpieczonych warunkach ${ }^{18}$. W latach 60. pojawiły się zakładane przez twórców filmowych Spółdzielnie Filmowe, których zadaniem było wspieranie realizacji projektów. Od 1966 r. wiele słoweńskich filmów powstawało w kooperatywie z belgradzkim Serwisem Spółdzielni Filmowych, który na początku lat 70. koprodukował również wiele filmów słoweńskich ${ }^{19}$.

Lata 70. otwierają trzy filmy poruszające dominujące w tym czasie tematy: antykołchozowe Czerwone klasy Živojina Pavloviča - adaptacja słoweńskiej literatury klasycznej ${ }^{20}$, utopijny Oxygen Matjaža Klopčiča - ukazujący hipisowską kontrkulturę czy też dekadencję rewolucji seksualnej ${ }^{21}$ oraz film Poza (1970) Jože Galeta - opowieść o czasach partyzanckich. W kinie drugiej połowy lat 70. coraz częściej pojawiała się nuta krytyki społecznej, odnoszącej się do życia zarówno w mieście, jak i na wsi, do rzeczywistości naznaczonej niepewnością, frustracjami i patologiami, defektami systemowymi i biurokratyzacją oraz różnymi formami kryzysu. Charakterystyczne są tu dwa filmy - Wdowieństwo Karoliny Žašler (Vdovstvo Karoline Žašler, reż. Matjaž Klopčič, 1976) opisujący tragedię kobiety w kontekście społeczno-politycznym oraz Skurcz (Krč, reż. Božo Šprajc, 1979), dramat o industrializacji wsi.

W połowie dekady Viba Film podjął próbę realizacji w koprodukcji z RTV Ljubljana wysokobudżetowego filmu partyzanckiego Bitwa nad Dražgošami (Dražgoška bitka) - niepowodzenie tego przedsięwzięcia okazało się dla Viby fatalne w skutkach i na przełomie lat 70. i 80. przedsiębiorstwo niemalże upadło ${ }^{22}$. Pomimo trudności finansowych udało się jednak utrzymać ciągłość produkcji.

Przeniesienie punktu ciężkości na nową tematykę zapowiadają Poszukiwania (Iskanja, 1979) Klopčiča na podstawie powieści Izidora Cankara. W filmie tym ksiądz i historyk sztuki wyprawiają się w podróż do Włoch (przed I wojną światową) oraz deliberują na temat roli sztuki w życiu. Kwestie wartości intelektualnych i sztuki jako wyższego sensu życia to wątki sygnalizujące koniec okresu proletariackiego. Poszukiwanie niekonwencjonalnych możliwości języka filmowego można dostrzec natomiast w Czasie kryzysu (Krizno obdobje, 1981) - debiucie absolwenta Łódzkej Szkoły Filmowej Franci Slaka oraz Karpo Godina, który wcześniej eksperymentował z formułą postmodernistyczną w Tratwie meduzy (Splav meduze, 1980), będącej hołdem dla rodzimej awangardy lat 20. W latach 80. jednym z przewodnich tematów filmowych stały się także wydarzenia związane z Kominformem. Dobrym przykładem może tu być tragikomedia Czerwone boogie albo Co ci dolega dziewczyno (Rdeči boogie ali Kaj ti je deklica, 1982) Karpo Godiny, opowiadająca o rewolucyjnej polityce kulturowej i cenzurze niepoprawnych gatunków muzycznych, w tym jazzu. W filmie tym pojawiła się śmietanka ówczesnej słoweńskiej muzycznej sceny rockowej i punkowej od Zorana Predina z grupy Lačni Franc, po Petra Mlakara, Igora Vidmara czy Petra Lovšina z grupy Pankrti. Z kolei przeświadczenie, że nad krajem zbierają się czarne chmury można dostrzec w dość proroczym filmie Živojna Pavlovicia Do zobaczenia na następnej wojnie (Nasvidenje v naslednji vojni, 1980). Podczas wakacji w Hiszpanii spotykają się były słoweński partyzant i niemiecki żołnierz, który niegdyś walczył w Jugosławii. W swoich rozmowach przywołują wspomnienia czasu wojennego, kiedy to przecież byli wrogami. Niewygodne tematy poruszał też Filip Robar Dorin, który w fil- 
mach Opre Roma (1983), Barany i mamuty (Ovni in mamuti, 1985) oraz Wiatr $w$ sidtach (Veter $v$ mrež $i, 1989$ ) pokazywał margines społeczny (Romowie, pracownicy sezonowi, ruchy alternatywne czy też ludzie nieprzystosowani). Co ciekawe, filmy te oraz rzeczywiste zaangażowanie ich twórcy wymogły na władzach realną poprawę warunków życia tych grup ${ }^{23}$.

W drugiej połowie lat 80 . cały kraj zaczął pogrążać się w chaosie, wszystko wymykało się spod kontroli. Poważny kryzys ekonomiczny i polityczny prowadził nieuchronnie do rozpadu państwa. Dla rodzimej kinematografii konkurencją, obok silnej dominacji filmów hollywoodzkich i programów telewizyjnych, stały się także kasety wideo, które pod koniec dekady dosłownie zalały rynek jugosłowiański, w tym także nierespektujący praw autorskich czarny rynek, co uderzyło przede wszystkim w przemysł filmowy. Program kinowy i telewizyjny nie był w stanie konkurować z ogromnym wyborem filmów na kasetach. Jakość kopii zazwyczaj była słaba, filmy były wielokrotnie przegrywane, chociaż jak pisze Peter Stankovič, wideo stało się ważną częścią kultury filmowej tego czasu: Z jednej strony przyczyniło się do kilkakrotnego spadku frekwencji w kinach, z drugiej zaś spopularyzowało film i zwiększyło stopień ogólnej świadomości filmowej. W tym czasie byty bardzo popularne „imprezy wideo”, podczas których przez cały wieczór (czasem nawet do rana i dtużej) oglądało się filmy ${ }^{24}$.

Stankovič twierdzi również, że w tych latach bezpośredni kontekst rodzimej produkcji filmowej $w \dot{z} a d n e j$ mierze nie byt słaby, jednakże filmowi, który był zależny od dotacji, za bardzo to nie pomogło ${ }^{25}$. Mimo wszystko lata 80 . nie były złe pod względem produkcji, nakręcono bowiem ok. 50 filmów pełnometrażowych oraz pierwszy tzw. niezależny - bo zrealizowany poza głównymi strukturami produkcyjnymi - film: Decydujacy telefon (Usodni telefon, 1986) Damjana Kozolego i Danijela Hočevara ${ }^{26}$. To czas przełomu w liberalizacji słoweńskiej kinematografii, co można było zaobserwować także w innych sferach rzeczywistości społecznej; wszak socjalizm, najpierw jako doktryna ekonomiczna, a chwilę później również polityczna, zbliżał się ku końcowi.

Na podstawie decyzji plebiscytowej 25 czerwca 1991 r. Słowenia ogłosiła swoją niepodległość. Kraj odłączył się od Socjalistycznej Federacyjnej Republiki Jugosławii. Nastąpiła dwutygodniowa wojna niepodległościowa oraz pełen turbulencji rok przemian. W 1992 r. Słowenię uznano za niepodległe państwo. Ten okres przejściowy oznaczał zmiany także dla twórców filmowych - RTV Ljubljana została automatycznie „zrenacjonalizowana” i przekształcona w RTV Slovenija, natomiast przedsiębiorstwo filmowe Viba Film, już wcześniej borykające się z trudnościami, było o krok od likwidacji. Po uzyskaniu niepodległości i przemianach demokratycznych na początku lat 90. samodzielna Republika Słowenia przejęła odpowiedzialność za subwencjonowanie i współfinansowanie słoweńskich produkcji filmowych. Sami filmowcy sugerowali władzy: aby rozpoczęła wdrażanie ustawy o kinematografii produkcyjnej i reprodukcyjnej, a także by $w$ budżecie krajowym zostały zapewnione docelowe środki na produkcję filmowa w kolejnym roku ${ }^{27}$.

Na łamach magazynu „Ekran” toczyły się dyskusje o nowym instytucyjnym modelu kinematografii słoweńskiej, który miał się wzorować na innych mniejszych kinematografiach europejskich, np. takich jak austriacka (finansowana w 40\% przez Fundusz Filmowy, w 40\% przez telewizję i 20\% przez producenta). Przy czym sama instytucja producenta stanowiła w tym przypadku niewiadomą. W okre- 
sie przejściowym Ministerstwo Kultury znalazło fundusze na produkcję filmową i przejęło nad nią opiekę aż do 1994 r. Sprzęt techniczny został odziedziczony po Viba Film, który stał się jednostką publiczną. W 1992 r. upadło państwowe przedsiębiorstwo dystrybucyjne Vesna Film, a w jego miejsce pojawiły się mniejsze firmy (Mladina Film, Lublańskie Przedsiębiorstwo Kinematograficzne). Na początku (głównie za pośrednictwem dystrybutorów chorwackich ${ }^{28}$ ) miały one wyłączność na dystrybucję najbardziej pożądanych filmów hollywoodzkich.

Wedle historyków filmu, którzy analizowali okres przejściowy, w latach 90. istniały cztery przedsiębiorstwa kinematograficzne z 21 kinami, a także sale stowarzyszeń kulturalnych bądź instytucji ${ }^{29}$.W 1945 r. mieliśmy 45 kin, najwięcej, bo 263, w roku 1964, później ich liczba zaczęła mocno spadać, by w 1990 r. osiagnać liczbę zaledwie 90. W ostatnich latach znów wzrasta zainteresowanie filmem, a niektóre nasze kina sa całkowicie ,zamerykanizowane” [wyświetlają tylko filmy amerykańskie] ${ }^{30}$. Sytuacja się pogorszyła, kiedy otwarto kompleks Kolosej w centrum handlowym w Lublanie, co spowodowało zamykanie kin, ujednolicenie programu bazującego na produkcjach amerykańskich oraz spadek oglądalności filmu słoweńskiego.

W 1994 r. ustanowiono Fundusz Filmowy Republiki Słowenii, który od 1995 r. zapewniał ciągłość programową, kreślił plany i umożliwiał produkcję filmową współfinansowaną z budżetu państwowego. Instytucja ta przejęła w spadku po Vesna Filmie pomieszczenia, w których dziś mieści się część Kinoteki ${ }^{31}$. W nowo powstałym państwie Fundusz Filmowy przyczynił się do odrodzenia kina słoweńskiego, a także do powstania nowej fali filmów, realizowanych przede wszystkim przez młodsze pokolenie reżyserów. Owa nowa generacja to pierwsze z ważnych zjawisk w kinie niepodległej Słowenii. Drugim natomiast jest odejście od tzw. filmu dziedzictwa. Tak jak państwo wybiło się na niepodległość, tak film i sztuka w ogóle w pewnym sensie wyzwoliły się z literackich okowów.

Ten nowy początek i wielkie nadzieje na sukcesy młodego kina słoweńskiego otworzył film Babcia jedzie na południe (Babica gre na jug, 1991) Vinciego Vouge Anžlovara. Filmową i reżyserską karierę rozpoczęli młodzi reżyserzy, tacy jak Metod Pevec (Carmen, 1995), Igor Šterk (Ekspres, ekspres, 1996), Andrej Košak (Outsider, 1997), Damjan Kozole (Stereotyp /Stereotip/, 1997), Janez Burger (Na luzie /V leru/, 1998), Sašo Podgoršek (Ciemne anioły losu /Temni angeli usode/, 1999). Jak pisze Andrej Šprah, entuzjazm twórczy młodego pokolenia reżyserów drugiej połowy lat 90. i początku nowego tysiąclecia wybucha potężnym ładunkiem indywidualnych ,poetyk autorskich”. W nich wyraża się kreatywne poświęcenie, które także w szerszym kontekście europejskich kinematografii narodowych (...) z pewnościa osiaga wysoki, wart uwagi poziom ${ }^{32}$.

W 1998 r. kraj doczekał się własnego Festiwalu Filmu Słoweńskiego. Zorganizował go Fundusz Filmowy, a nagrodą na nim wręczaną jest Vesna ${ }^{33}$. Jako pierwszy otrzymał ją pełnometrażowy film animowany Socjalizacja byka? (Socializacija bika?, 1998) Zvonka Čoha i Milana Eriča.

W kolejnych dwóch dekadach od 1991 r., pomimo trudności związanych z transformacją oraz systemowymi i instytucjonalnymi zmianami, powstało w Słowenii ok. 90 filmów fabularnych, co można porównać z poziomem produkcji Viba Film w ostatnich 30. latach jego działalności. Zdenko Vrdlovec widzi w tym dowód na to, że pluralizm w ruchu producenckim byt płodniejszy niż monopol producencki 
Viby ${ }^{34}$. Lata 1997-2002 to okres rozkwitu filmu słoweńskiego (to także czas kadencji Filipa Robara Dorina jako dyrektora Funduszu Filmowego). Według Zdenka Vrdloveca film stoweński dopiero $w$ drugiej połowie lat 90. sam stat się faktycznie forma kultury masowej, w niektórych przypadkach zaś też współczesnej sztuki filmowej ${ }^{35}$. W nowym tysiącleciu przyniósł efekty plan rozwoju kinematografii, co uwidoczniło się w postępie ilościowym, a przede wszystkim jakościowym. Nowością było pojawienie się w kinie słoweńskim pierwszych reżyserek (Hanna A. Wojcik-Slak, Maja Weiss) oraz filmowców o mocnym rysie autorskim (Jan Cvitkovič). W latach 2000 i 2001 film słoweński osiągnął rekordową liczbę 11 produkcji i chociaż w 2000 r. frekwencja w kinach spadła do 2 mln widzów, to jednak już od połowy lat 90 . kina zanotowały zwiększoną oglądalność filmów słoweńskich.

Bez wątpienia momentem przełomowym dla słoweńskiej produkcji filmowej był rok 2001. Słowenia stała się wówczas pełnoprawnym członkiem europejskiego koprodukcyjnego funduszu Eurimages, z którym w pierwszym roku przynależności współpracowali też - jako partnerzy mniejszościowi, oprócz Funduszu - dwaj słoweńscy producenci ${ }^{36}$. Owocem tej współpracy był film Ziemia niczyja (Ničija zemlja) Danisa Tanovicia, który zdobył nagrodę za najlepszy scenariusz w Cannes oraz Oscara za najlepszy film nieanglojęzyczny.

We wrześniu tego samego roku młody słoweński reżyser Jan Cvitkovič otrzymał na festiwalu w Wenecji Lwa Przyszłości za film Chleb i mleko (Kruh in mleko, 2001). Był to pierwszy Lew w historii kina słoweńskiego od czasu Kekca Jože. Inspiracją filmu było wspomnienie Cvitkoviča: obraz pijanego mężczyzny ujrzanego pewnego wczesnego ranka przy barze w lokalnym pubie, trzymającego w ręku siatkę z chlebem i mlekiem ${ }^{37}$. Stał się on podstawą historii o dysfunkcyjnej rodzinie - mężu Ivanie, żonie Sonji i nastoletnim synu Robim, którzy wegetują w biedzie w małym, zapomnianym miasteczku, pozostawieni sami sobie, niezdolni do dialogu i zrozumienia, osamotnieni i wyobcowani. Temat dysfunkcji, niezdrowej dynamiki relacji w rodzinie czy też zjawisk takich jak depresja, samobójstwa, problemy mężczyzn czy wykorzystywanie kobiet z marginesu społecznego (nawet jeśli bohaterowie filmowi pochodzą z klasy średniej, stoją na krawędzi ubóstwa) podejmuje Cvitkovič także w kolejnych filmach Od grobu do grobu (Odgrobadogroba, 2005) czy też w najnowszym Rodzinka (Družinica, 2018). Tragedie rodzinne Cvitkoviča mają swoiste (ironiczne) szczęśliwe zakończenie. Sam reżyser mówi, że poprzez film stara się stworzyć rodzinkę na nowo ${ }^{38}$.

Początek XXI w. to czas prawdziwego rozkwitu nowej fali słoweńskich filmów młodych reżyserów. Wiele z nich odniosło sukces, jak na przykład Kurde (Jebiga, 2000) Mihy Hočevara, Porno film (2000) Damjana Kozolego, Stodkie sny (Sladke sanje, 2001) Sašy Podgorška, Stróż graniczny (Varuh meje, 2002) Mai Weiss, Szelest (Šelestenje, 2002) Janeza Lapajne, Zaćma (Slepa pega, 2002) Hanny A. Wojcik- Slak, Części zamienne (Rezervni deli, 2003) Damjana Kozolego, Ser $i$ marmolada (Kajmak in marmelada, 2003) Branka Đjurića, Pod jej oknem (Pod njenim oknom, 2004) Metoda Pevca, Przedmieście (Predmestje, 2004) Vinka Möderndorfera i Ruiny (Ruševine, 2004) Janeza Burgera. Filmy tego ostatniego skupiają się przede wszystkim na współczesności (okresie transformacji). Filmy takie jak Kurde czy Lublana (Ljubljana, reż. Igor Šterk, 2002) opowiadały o problemach miejskiego życia w nowej rzeczywistości. Poker (reż. Vinci Vouge Anžlovar, 2001), Zaćma, Przedmieście, Tu i tam (Tu pa tam, reż. Mitja Okorn, 2004), Stowenka (Slo- 


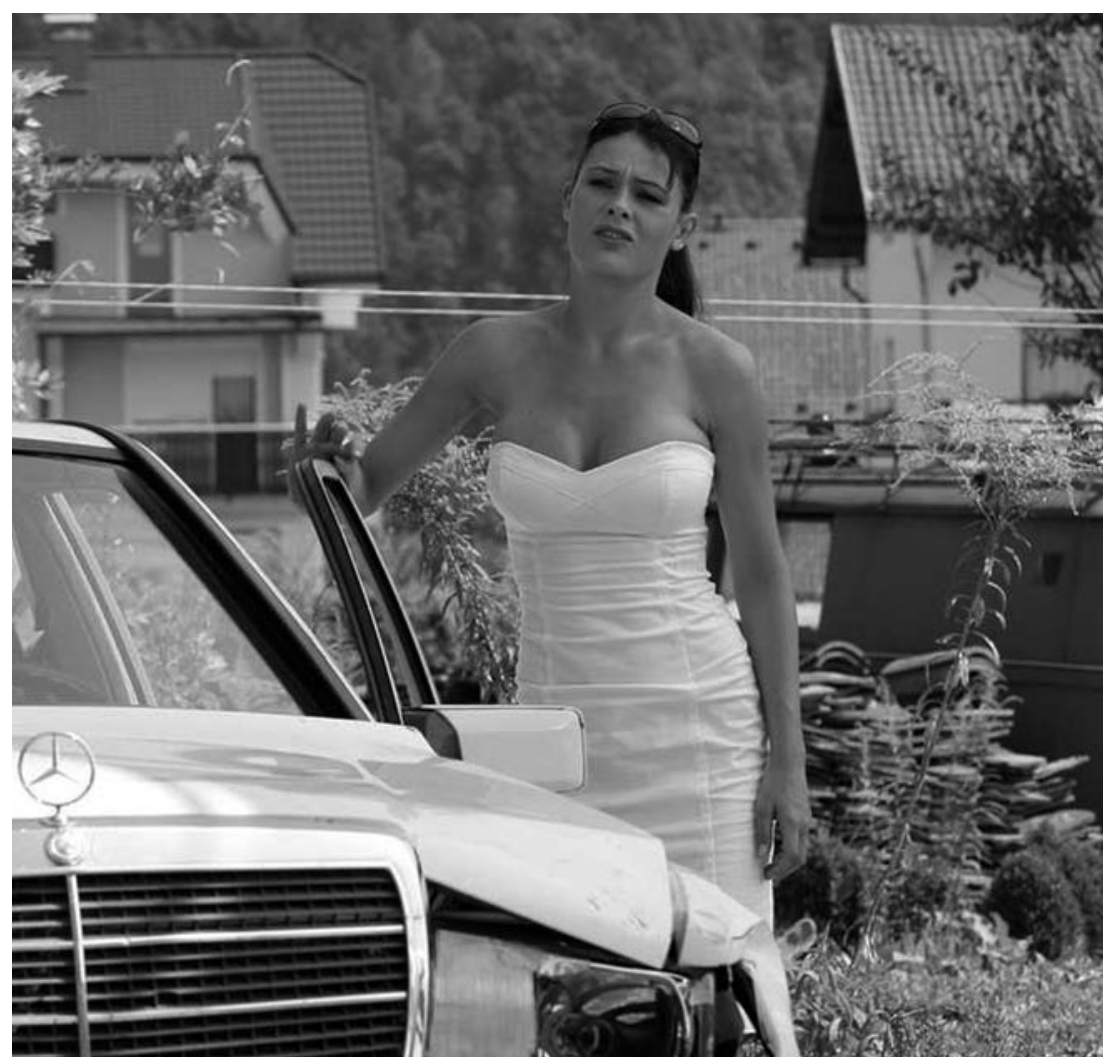

Śniadanie koguta, reż. Marko Naberšnik (2007)

venka, reż. Damjan Kozole, 2009) odnosiły się do współczesnego postsocjalistyczno-kapitalistycznego porządku świata i jego nowych (anty)bohaterów. Szelest czy Pod jej oknem mówiły o relacjach partnerskich, natomiast Amir - , szeryf z Nuricia” (Amir - „šerif iz Nurića”, reż. Miha Čelar, 2002), Ser i marmolada, W górach (Na planincah, reż. Miha Hočevar, 2003), Aven čhavora (reż. Filip Robar Dorin, 2005) o stosunku Słoweńców do nie-Słoweńców. Problematykę społeczną poruszały: Praca wyzwala (Delo osvobaja, reż. Damjan Kozole, 2005), Strojenie (Uglaševanje, reż. Igor Šterk, 2005), Strażnik granicy, Od grobu do grobu, Krótkie spięcia. Rzadko poruszano kwestie z przeszłości - a jeśli już, to przeszłość ta dotyczyła Jugosławii, jak w Słodkich snach lub L jak Love (L kot ljubezen, reż. Janja Glogovac, 2007).

W 2002 r. zadebiutowały dwie reżyserki, Maja Weiss ${ }^{39}$ i Hanna Antonina Wojcik-Slak ${ }^{40}$ - przed nimi w filmie słoweńskim nie zaistniała ani jedna kobieta. Strażnik granicy Mai Weiss to odważny film drogi, opowiadający o swoistej odysei trzech studentek, które podróżując po rzece Kupie (ta pełni funkcję granicy państwowej), eksplorują inne rodzaje granic - od osobistych, tych związanych z patriarchatem, po (homo)seksualne i tożsamościowe. Jak pisze Mateja Valentinčič: mężczyźni, jako uprzywilejowani przedstawiciele ideologii spolecznej, strażnicy granic, to ci, wobec których dziewczęta w filmie musza zbudować jakąś relację, jeśli chca stać się kobietami, przy czym każda doznaje nowego odkrycia samej siebie ${ }^{41}$. 

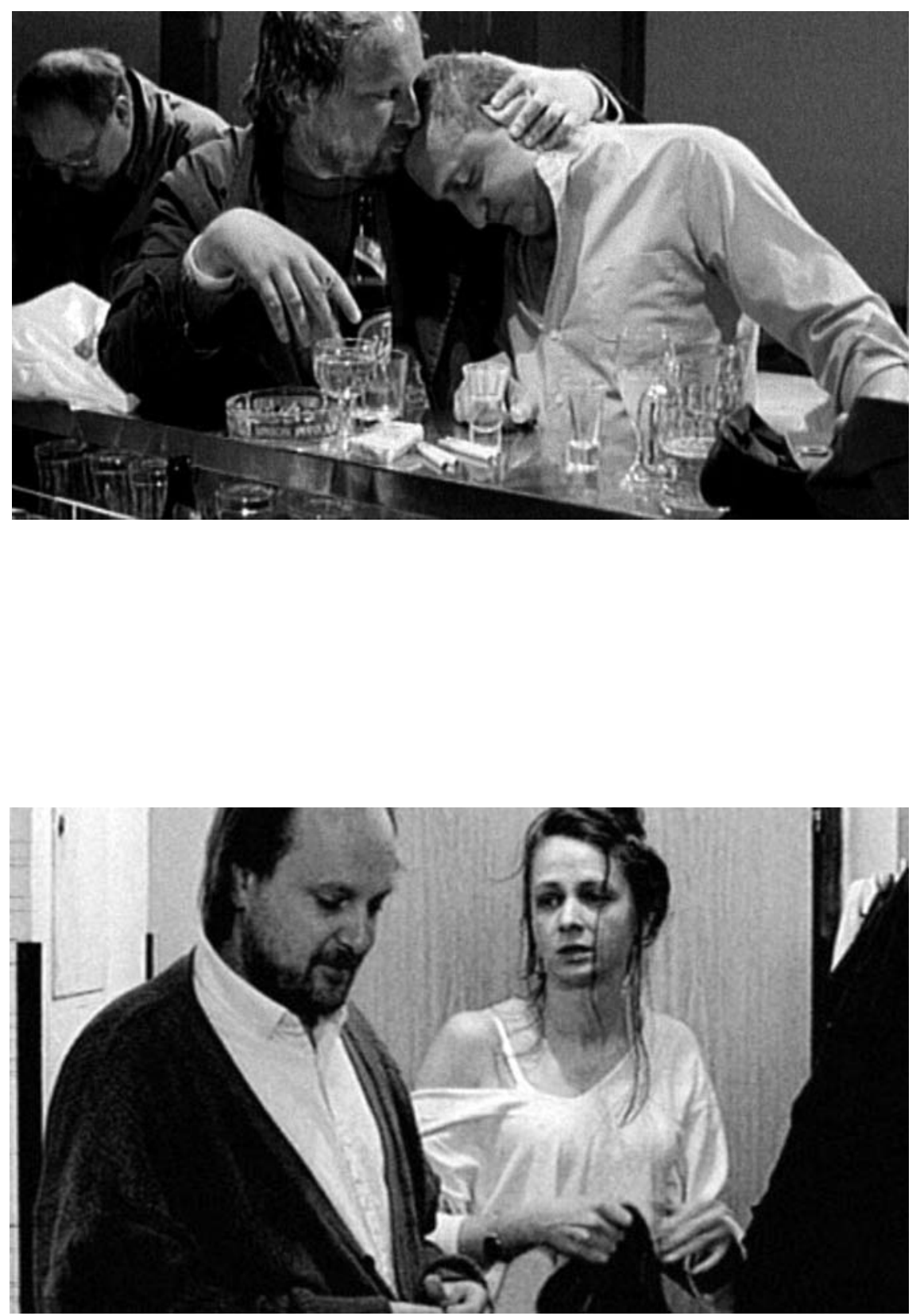

Chleb i mleko, reż. Jan Cvitkovič (2001) 

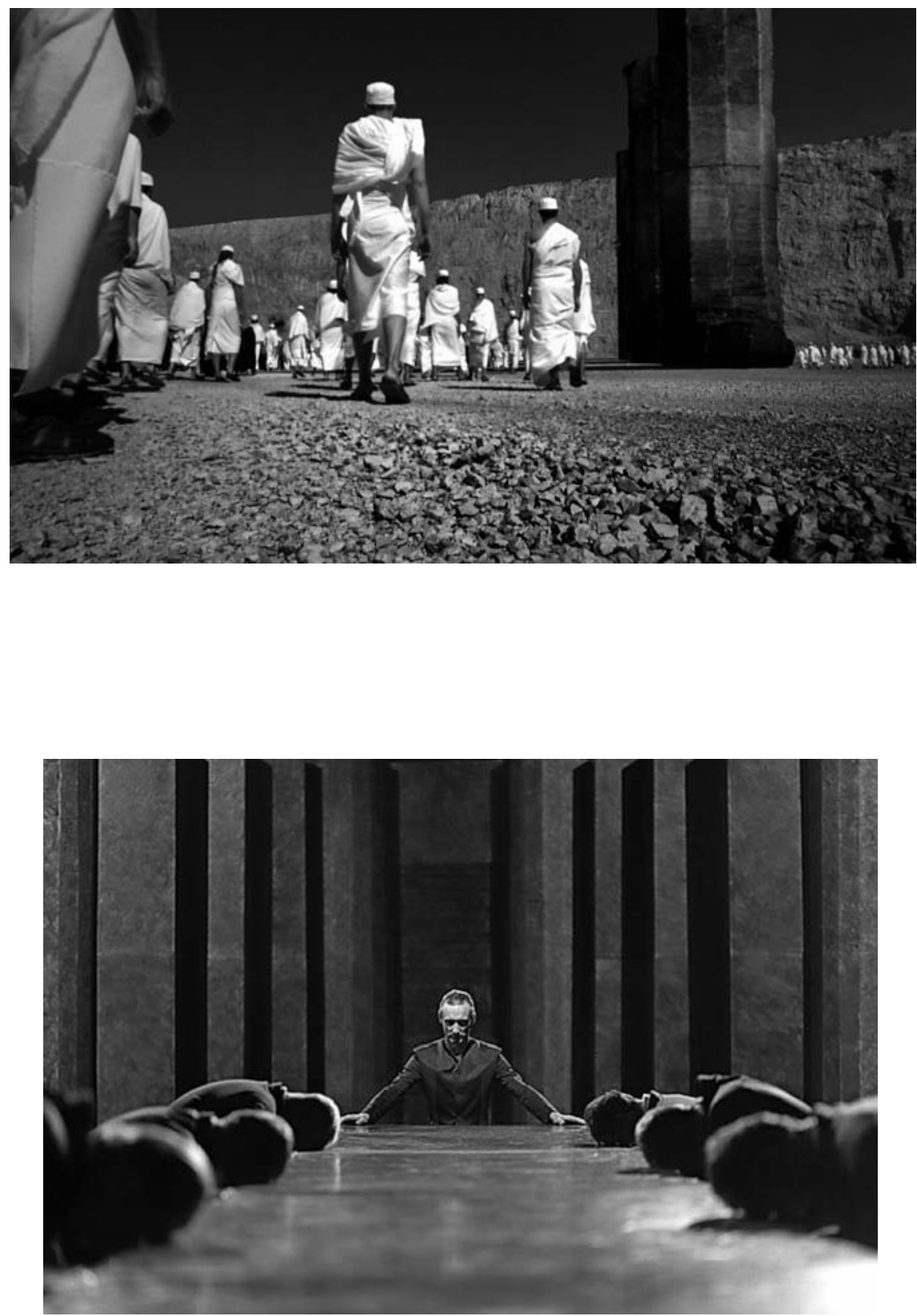

Echa czasu, reż. Ema Kugler (2013) 

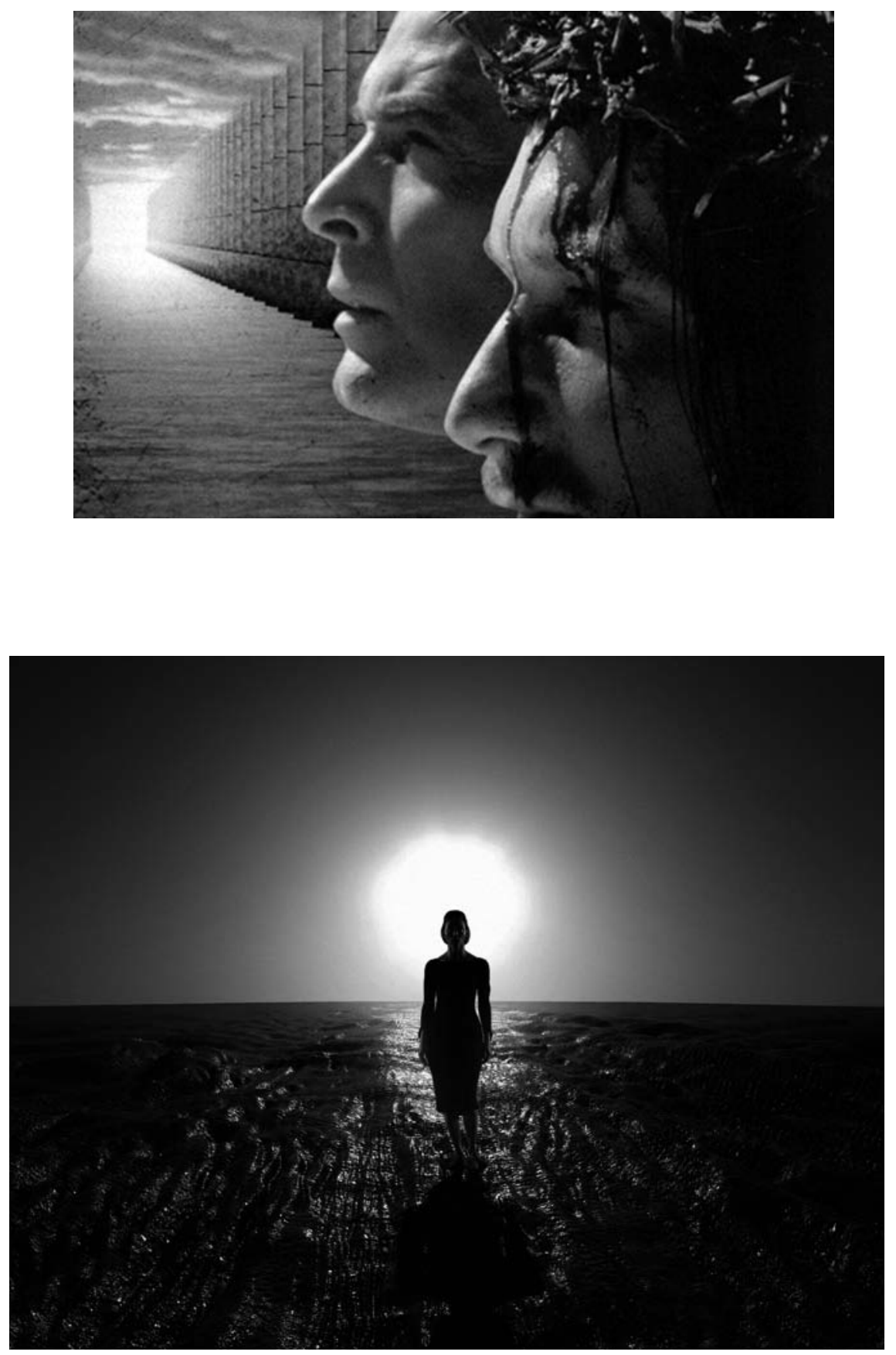

Echa czasu, reż. Ema Kugler (2013) 
Filmem tym Maja Weiss otworzyła kontrnarrację wobec męskiego świata filmu słoweńskiego. I rzeczywiście, początek nowego tysiąclecia przyniósł wzbogacenie tej kinematografii o kobiece spojrzenie na świat. Pojawiło się wiele utalentowanych autorek, na przykład Špela Kuclar z młodzieżowym Życie jak w filmie (Živjlenje kot v filmu, 2005), a przede wszystkim Ema Kugler, której autorski film Echa czasu (Odmevi časa, 2013) zgarnął pokaźną pulę nagród i został uznany przez „The Los Angeles Review" za najlepszy film obcojęzyczny ${ }^{42}$. Kolejną młodą utalentowaną reżyserką jest Urša Menart, która we współczesnym debiucie Juz nie będę loserka (Ne bom več luzerka, 2017) opowiada o trudnościach dorosłego życia 30-letniej Špeli.

Mimo sukcesów produkcyjnych w kolejnym dziesięcioleciu wiele rzeczy w strukturach słoweńskiego świata filmowego potoczyło się niewłaściwym torem. Nie zdołano uchwalić prawa filmowego, ciemne chmury wciąż wiszą nad Funduszem Filmowym. Lata po 2003 r. to czas niepewności i perturbacji: dymisji, zmian, zwolnień dyrektorów, a także komplikacji i nieprawidłowości przy konkursach. Do pozytywów należy otwarcie w tymże roku nowych pomieszczeń Viba Film, tzw. słoweńskiej fabryki snów, wzniesionych w opuszczonej strefie przemysłowej w Stegnach ${ }^{43}$. W tym samym czasie w Lublanie rozpoczął działalność Kinodvor, mający stanowić alternatywę wobec komercyjnego kina mainstreamowego. Nad jakością programu filmowego i programem upowszechniania kultury filmowej czuwał ówczesny dyrektor Kinoteki Słoweńskiej, Silvan Furlan.

Niestety, kinematografią słoweńską wstrząsały skandale wokół Funduszu Filmowego oraz Ministerstwa Kultury, zwłaszcza w dziedzinie finansowania. $\mathrm{Na}$ przykład w 2005 r. za najbardziej udany film (również o największej oglądalności) uznano Tu i tam Mitji Okorna ${ }^{44}$, poruszający kwestie finansowania publicznego i innych problemów tej branży. Amatorski film młodzieżowy Okorna nie był dotowany przez państwo (a wniosek o dofinansowanie przekopiowania filmu na taśmę został odrzucony przez Fundusz Filmowy). Kontrowersje wokół Tu $i$ tam osiągnęły szczyt, gdy nie zakwalifikowano go do udziału w Festiwalu Filmu Słoweńskiego. Przy tym był to jedyny słoweński film, który w tym samym roku znalazł się w programie międzynarodowego festiwalu LIFFe w Lublanie. Okorn komentował konflikt z instytucją Funduszu następująco: Fundusz Filmowy najwyraźniej ogłosit konkurs na dofinansowanie tylko z powodu przepisów prawnych, wszak jasne byto, że nie ma pieniędzy. Mój film natomiast automatycznie zostat uznany za ,mniej wartościowy”, jako że byt zrealizowany bez pomocy Funduszu. Jednak film będzie dystrybuowany, przecież musi dotrzeć do swojej publiczności w taki czy inny sposób. Widzimy się w kinach w styczniu ${ }^{45}$.

W 2007 r. nastąpiła swego rodzaju kumulacja problemów kadrowych Funduszu oraz konfliktów z Ministerstwem Kultury, co zaktywizowało Stowarzyszenie Słoweńskich Twórców Filmowych. Działalnością Funduszu zainteresowała się natomiast słoweńska Najwyższa Izba Kontroli, która jak pisze Vrodlvec, rewidowała prawidłowości i funkcjonowanie Funduszu Filmowego i Ministerstwa Kultury w okresie od 28 czerwca 2006 do 31 maja 2008, a w roku 2009 (lipiec) wyrazita negatywna opinię zarówno o Funduszu, jak i o Ministerstwie ${ }^{46}$. W przypadku Funduszu odkryto przede wszystkim nieprawidłowości w przyznawaniu dotacji projektom i swoistą protekcję w stosunku do tych, które nie spełniają warunków. Postawiono też zarzuty braku kontroli nad dysponowaniem środkami, decyzjami o przedlużaniu wykonywania projektów oraz powodami wydawania dodatkowych 
środków w celu realizacji projektów ${ }^{47}$. Ministerstwu postawiono zarzut braku kontroli nad Funduszem Filmowym.

Największy hit kinowy tego czasu także powstał bez subwencji Funduszu Filmowego - Wytwórnia Arsmedia w koprodukcji z zagrzebskim Jadran Film i RTV Slovenija w roku 2007 r. zrealizowała komedię Śniadanie koguta (Petelinji zajtrk). Rozprawiający się z okresem transformacji debiut Marka Naberšnika, nakręcony na podstawie powieści Feriego Lainščka o tym samym tytule (który potocznie oznacza poranny seks), stał się najchętniej oglądanym słoweńskim filmem wszech czasów i jednym z największych sukcesów kinowych po uzyskaniu niepodległości. $\mathrm{W}$ filmie pojawia się jedna $\mathrm{z}$ najpopularniejszych piosenkarek popowych obszaru byłej Jugosławii, Severina.

Po trwających pół roku burzliwych dyskusjach we wrześniu 2010 r. przyjęto ustawę o Słoweńskim Centrum Filmowym (wcześniej Fundusz Filmowy), która definiowała i regulowała prawnie jego rolę, w tym także subwencjonowanie ${ }^{48}$ główny przedmiot dotychczasowych sporów. Przed przyjęciem ustawy sprawa została nagłośniona w słoweńskich mediach, w których filmowcy (np. Damjan Hočevar w gazecie ,, Dnevnik”) wyrażali swoje niezadowolenie: Stowenia była wzorem dla wszystkich państw tak zwanej nowej Europy, wszak w momencie ustanowienia Funduszu Filmowego w 1994 r. byta pierwszym krajem, który, chociaż z pewnymi niedociagnięciami, uporządkowat obszar kinematografii. Dziś natomiast jest daleko $w$ tyle. Większy bałagan $w$ kinematografii maja już tylko kraje spoza $U E^{49}$.

Wraz z początkiem działalności Słoweńskiego Centrum Filmowego w styczniu 2011 r. otrzymało ono jasno zdefiniowane zadania, których streszczony, wypunktowany wykaz znalazł się na stronie internetowej Centrum. Zapisano tam m.in., że Centrum: odpowiada za realizację programu kulturalnego $w$ dziedzinach, które dotycza działalności filmowej i audiowizualnej, a także monitoruje i analizuje zakres swoich działań, dbajac przy tym o rozwój jakościowy działalności filmowej $i$ audiowizualnej, przyspiesza produkcje $w$ obszarze filmowym i audiowizualnym oraz dba o wykazywanie osiagnięć w tym zakresie, a także decyduje o wyborze projektów w ramach działalności filmowej i audiowizualnej, które sa finansowane ze środków publicznych, a z wybranymi wnioskodawcami tych projektów zawiera umowy o finasowaniu ${ }^{50}$.

Od tego momentu sytuacja w kinematografii zaczęła się poprawiać. W $2010 \mathrm{r}$. powstały też pierwsze multipleksy, do łask powróciły pojedyncze kina, jak np. lublańskie Kino Komuna, Kino Šiška, Kino Bežigrad, a takie placówki jak Kino Dvor czy Słoweńska Kinoteka zaoferowały bogaty program będący alternatywą dla głównego nurtu. Wysoką frekwencją cieszą się też festiwale i inne wydarzenia związane ze sztuką filmową. W 2010 r. odnotowano najwyższy dotąd udział widzów w projekcjach filmów słoweńskich $(6,7 \%)$, przy czym liczba ta dla filmu amerykańskiego wciąż jeszcze sięga $80 \%{ }^{51}$. Na produkcję filmową Fundusz Filmowy/Centrum Filmowe przeznaczył 4439853 euro z budżetu kształtującego się na poziomie ok. $5 \mathrm{mln}$ euro. Kina odwiedziło 2888391 widzów, a najchętniej oglądanym filmem tego roku była słoweńska komedia młodzieżowa Idziemy po swoje (Gremo mi po svoje, reż. Miha Hočevar, 2010) z publicznością 208.370 widzów (wszystkie pozostałe filmy pierwszej dziesiątki były produkcjami amerykańskimi) ${ }^{52}$. 
Produkcja filmu słoweńskiego znalazła się pod kuratelą nie tylko Centrum Filmowego, ale też Dyrekcji Krajowych Filmów i Seriali RTV Slovenija oraz kilku wytwórni, takich jak Arsmedia, Staragara czy Vertigo. Dzięki temu w ostatnich latach powstało kilka ważnych produkcji: film drogi Wycieczka (Izlet, reż. Nejc Gazvoda, 2011), opowieść o drugim pokoleniu imigrantów Czefurzy raus! (Čefurji raus!, reż. Goran Vojnović) ${ }^{53}$, debiut Roka Bičeka Klasowy wróg (Razredni sovražnik, 2013), kameralny dramat Drzewo (Drevo, reż. Sonja Prosenc, 2014), horror Idylla (Idila, reż. Tomaž Gorkič, 2015), „sokurowska” Mama (reż. Vlado Škafar, 2016), a także wspomniana Rodzinka Jana Cvitkoviča (2017) czy też współczesny dramat Ivan (reż. Janez Burger, 2017).

Okres po uzyskaniu niepodległości (1991-2011) to według Vrdlovca czas nowej fali w kinie słoweńskim, przede wszystkim dlatego, że prawie połowa filmów została nakręcona przez reżyserów młodego pokolenia. Jeśli jednak przyjrzeć się uważniej, falę tę reprezentują dwa pokolenia twórców. Można do niej zaliczyć zarówno reżyserów urodzonych w latach 60. i 70. ubiegłego wieku, wciąż młodych, ale doświadczonych w zawodzie, takich jak Jan Cvitkovič, Miha Hočevar, Janez Burger, Metod Pevec, Hanna Wojcik-Slak, Igor Šterk, Marko Naberšnik czy Damjan Kozole, jak też i młodszą generację (twórcy urodzeni w latach 80.), która dołączyła do środowiska filmowego w ostatniej dekadzie. Są to m.in. Goran Vojnović, Rok Biček, Olmo Omerzu, Nejc Gazvoda czy Urša Menart.

Spoglądając na okres transformacji z szerszej perspektywy - od końca lat 70. do pierwszej dekady nowego millenium - można zauważyć, że kinematografia słoweńska stopniowo przechodziła intensywne przemiany. Mimo burzliwej historii społeczno-politycznej Słowenii i zmian systemowych związanych z transformacją kinematografii tej udało się zachować ciągłość produkcji, przeżyć kryzys gospodarczy, dostosować się do nowych światowych i europejskich standardów i zależności, związać się z lokalnym rynkiem i twórcami z krajów z byłej Jugosławii, a także zatroszczyć się o kulturę w Słowenii w ogóle (zwiększyła się liczba alternatywnych kin, projekcji, festiwali).

Sama sztuka filmowa, jakby przecięta nożem, dzieli się natomiast na dwa okresy: przed 1991 r. i po roku 1991, odcinając się gwałtownie, po uzyskaniu niepodległości, od adaptacji literackich. Wyzwoliła się także od przeszłości. Dziś niemal wszystkie filmy odzwierciedlają problemy współczesności, i jak pisze Pavle Levi, w twórczości młodego i starego pokolenia reżyserów w całej byłej Jugosławii pojawiają się świeże stylistyczne $i$ tematyczne tendencje ${ }^{54}$. Również „wybredny” widz słoweński, jak świadczą statystyki, pomimo szerokiej oferty telewizyjnej i internetowej, chętnie ogląda rodzime filmy, w przeciwieństwie do lat 80., kiedy to, jak pisał Štefančič, publiczność zrezygnowała z filmu słoweńskiego ${ }^{55}$. W $2011 \mathrm{r}$. Verdlovec podsumował dzieje rodzimego przemysłu filmowego w sposób następujący: $w$ ciagu 65 lat, o ile postrzegać ja w ciagłej formie, stoweńska kinematografia stworzyła kilka hitów, wychowała wielu filmowych autorów, zdobyła kilka międzynarodowych nagród, wielokrotnie zachwyciła krajowa publiczność, a momentami zaprezentowała się również zagranicznej publiczności ${ }^{56}$. Opinię tę spokojnie możemy powtórzyć również dzisiaj. 


\section{PERTURBACJE KINEMATOGRAFII SŁOWEŃSKIEJ}

${ }^{1}$ Aż do rozpadu monarchii austro-węgierskiej nie było samodzielnej produkcji słoweńskiej; pod względem repertuaru Księstwo Krainy było w podobnym położeniu co inne prowincje monarchii - przed I wojną światową także Słoweńcy oglądali wszystko, co było istotne w produkcji filmowej. (Zob. S. Furlan, Wstęp, w: J. Traven, Pregled razvoja kinematografje pri Slovencih (do 1918), Ljubljana 1992, s. 5). Za autora pierwszych 50 metrów filmu słoweńskiego uchodzi prawnik z Ljutomeru Karol Grossman, którego miłość do fotografii przekształciła się w pasję filmowania. Zachowały się trzy jego filmy: Wyjście z kościoła w Ljutomerze (Odhod od maše v Ljutomeru, 1905), Targ w Ljutomerze (Sejem w Ljutomeru, 1906) oraz $W$ rodzimym ogrodzie (Na domačem vrtu, 1906).

2 Zaraz po zakończeniu operacji wojennych, w maju 1945 r., radziecki Mosfilm zaczął realizować w koprodukcji z Jugosławią film W górach Jugosławii (U planinama Jugoslavije) w reżyserii Abrama Rooma i Eduarda Tisse. W pracy nad filmem uczestniczyli przyszli słoweńscy twórcy filmowi, np. France Štiglic, France Brenk czy Bojan Stupica. W górach Jugosławii był w rzeczywistości pierwszym filmem jugosłowiańskim, chociaż z powodu konfliktu między Titą a Stalinem na kilka dekad trafił na półki. Oficjalnie zaś za pierwszy film jugosłowiański uznano Slavicę Vjekoslava Africia (1947), który w filmie grał Rooma Dražę Mihajlovicia. Zob. P. Volk, Istorija jugoslovenskog filma, Beograd 1986, s. 137.

${ }^{3}$ Podczas II wojny światowej okupant skonfiskował właścicielom majątek kin oraz przedsiębiorstw dystrybucyjnych. To, co przetrwało wojnę, przeszło w ręce nowej władzy, tj. Państwowego Przedsiębiorstwa Filmowego bądź jego przedstawicielstw. Na przykład Przedsiębiorstwo Dystrybucji Filmowej Alfa (1937), które miało siedzibę w Mariborze oraz przedstawicielstwo w Zagrzebiu, w maju 1945 r. zostało przekazane Państwowemu Przedsiębiorstwu Filmowemu. Julij Guštin, współwłaściciel Alfy i właściciel Grajskiego Kina w Mariborze, już w 1946 r. oddał firmę w najem sektorowi państwowemu, a ostateczna nacjonalizacja przedsiębiorstwa i sali kinowej nastąpiła 28.04.1948 r. Źródło: archiwum własne rodziny Guštin (autorki).

${ }^{4}$ W latach 1944-1945 dostał on podobne wytyczne, jak te rekomendowane przez Wydział Agitacji i Propagandy KC Komunistycznej Partii Jugosławii. Różnica była tylko w tym, że plany słoweńskie uwzględniały wyższy stopień rozwoju kulturalnego Słowenii. Zob.
A. Gabrič, Slovenska agitpropovska kulturna politika: 1945-1952, Ljubljana 1991, s. 490.

${ }^{5}$ M. Štefančič Jr., Počemu? Hvala Bogu za Franceta Brenka!, „Kino!” 2012, nr 17-18, s. 15 .

${ }^{6}$ Zob. M. Rau-Selič, Slovenska filmska dediščina. Posvečeno 100-letnici slovenskega filma, w: Tehnični in vsebinski problemi klasičnega in elektronskega arhiviranja. Zbornik referatov z dopolnilnega izobraževanja, Maribor 4/2005, nr 1, s. 211-223, http://mail.pokarh-mb.si/fileadmin/www.pokarh-mb.si/pdf datoteke/Radenci2005/R-2005-RAU-SELIC.pdf (dostęp: 15.04.2019).

${ }^{7}$ Reżyser ten, o ogromnym dorobku filmowym, odegrał również istotną rolę $\mathrm{w}$ formowaniu i rozwoju systemu kinematografii narodowej. Był prezesem Stowarzyszenia Słoweńskich Twórców Filmowych, dyrektorem Viba Filmu, ministrem kultury, a także profesorem i dziekanem na AGRFT w Lublanie. W roku 2019, z okazji setnej rocznicy urodzin Štiglica, Kinoteka Słoweńska, Słoweńskie Centrum Filmowe oraz Słoweńskie Archiwum Filmowe realizują projekt 100 lat France Śtiglica. Zob. Kinoteka na Kulturnem bazarju: 100 let Franceta Štiglica, http://www.kinoteka.si/si/463/670/Kinoteka na Kulturnem bazarju_100_let_Franceta_stiglica.aspx (dostęp: 15.04.2019).

${ }^{8}$ Titowska władza nie koncentrowała się jedynie na rekonstrukcji i budowie nowego państwa, ale też na formowaniu jego wizerunku, wizerunku samego Tity i kreowaniu kultu jego jednostki. Ten opierał się na fundamencie zwycięstwa w II wojnie światowej i przedstawiał Titę jako wodza i bohatera. Dlatego nie mogło być zaskoczeniem, że centralne miejsce w nowej kinematografii jugosłowiańskiej zajął film wojenno-partyzancki z akcją rozgrywającą się w latach 1941-1945. Film koncentruje się na walce $z$ faszystowskim okupantem i bohaterstwie partyzantów pod przywództwem Josipa Tity. Więcej na temat filmu partyzanckiego w monografii: Partisants in Yugoslavia. Literature, Film and Visual Culture, red. M. Jakiš, N. Gilić, Bielefeld 2015. Od Vardaru po Triglav nakręcono bardzo wiele filmów partyzanckich, w tym blockbustery czy też filmy przeznaczone dla widowni zagranicznej, jak na przykład Bitwa nad Neretwa (Bitka za Neretvo, reż. Veljko Bulajić, 1968), Valter broni Sarajewa (Valter brani Sarajevo, reż. Hajdurin Krvavac, 1972) czy Piata ofensywa (Sutjeska, reż. Stipe Delić, 1973). Nawet l'enfant terrible kina słoweńskiego, Boštjan Hladnik, nakręcił film partyzancki Czas bez bajek (Čas brez pravljic, 1986). Wspo- 


\section{MAŠA GUŠTIN}

minał później: Bojan Štih, dyrektor Viby, powiedział mi: każdy reżyser stoweński nakręcit film partyzancki i ty też nakręcisz. I nakręciłem. M. Štefančič Jr., Na svoji zemlji. Zgodovina slovenskega filma, Ljubljana 2005, s. 145.

${ }^{9}$ Štiglic pojawił się tam jeszcze w 1957 r. z Dolina pokoju (Dolina miru), za który to film był jako pierwszy słoweński reżyser nominowany do Złotej Palmy. Filmy Štiglica pokazano również w sekcji klasyków w Cannes: w 2016 r. Doline pokoju, a w 2019 r. Na własnej ziemi.

${ }^{10} \mathrm{~W}$ pierwszej połowie lat 50. sztuka uwolniła się od wzorców radzieckiej estetyki socrealistycznej.

${ }^{11}$ Więcej na stronie Viba Filmu, https://www.vibafilm.si/o-nas/zgodovina. (dostęp: 15.04.2019).

${ }^{12}$ Hladnik, jak większość twórców Nowego Filmu Jugosłowiańskiego, zaczynał w 1947 r. w amatorskim klubie kinowym. Amatorska twórczość filmowa w Jugosławii była bardzo ceniona, kluby gromadziły setki wielbicieli i stały się prężnymi centrami kultury. Młodzi twórcy próbowali tam swoich sił, kręcili i oglądali filmy, prowadzili dyskusje. Dwa lata później Hladnik studiował w Akademii Sztuki Filmowej w Lublanie, a w 1957 r. wyjechał do Paryża na Sorbonę. Tam przez kilka lat pracował jako asystent Claude'a Chabrola, Philippe'a de Broki i Roberta Siodmaka. (Zob. G. De Cuir Jr., Jugoslovenski crni talas. Polemički film od 1963 do 1972 u Socijalističkoj Federativnoj Republici Jugoslaviji, Beograd 2011, s. 23). Przy okazji stulecia kina słoweńscy krytycy filmowi ogłosili Taniec $w$ deszczu najlepszym filmem słoweńskim wszech czasów. Zob. M. Guštin, Kratek oris zgodovine slovenskega filma, w: Svetovni dnevi slovenskega filma. Od 21. do 24. novembra 2005, Ljubljana 2005.

${ }^{13} \mathrm{Na}$ przykład film drogi w reżyserii Hladnika Zamek z piasku (Peščeni grad, 1962) czy Kłamczucha (Lažnivka, 1965) Igora Pretnara. Zarówno Zamek z piasku Hladnika, jak i debiut Aleksandra Petrovicia Dni (Dani, 1964) nie spotkały się z pozytywnym odbiorem starszego pokolenia, zwłaszcza tego będącego u władzy, przede wszystkim z powodu przedstawionego w nich wizerunku młodych. Oba filmy nie zostały dopuszczone do konkursu festiwalu w Puli ani do udziału w zagranicznych festiwalach. W 1963 roku Kokan Rakonjac, Marko Babac i Živojin Pavlović nakręcili Miasto (Grad, 1963) składające się z trzech nowel. Dystrybucja i projekcja tego filmu zostały zakazane sądowo. Jest to jedyny taki przypadek w historii kina jugosłowiańskiego. Sąd nakazał spalenie taśm filmowych, jednak udało się je zachować w archiwum.

${ }^{14}$ Zob. P. Volk, Istorija... dz. cyt., s. 319.

${ }^{15}$ Matjaž Klopčič ukończył podyplomowe studium reżyserii w Paryżu, gdzie w 1964 r. asystował przy kryminale Jeana-Luca Godarda Amatorski gang (Bande à part, 1964). W efekcie jego pierwsze filmy zostały zrealizowane w stylu nowej fali. Jest on jednym z reżyserów słoweńskich o największym dorobku filmowym. Zob. Matjaž Klopčič. Eseji in pričevanja, red. A. Šprah, Ljubljana 2012.

${ }^{16}$ Jak pisze Stankovič, jedną z głównych przyczyn problemów w Triglav Film było to, że przynajmniej część zarobków studia z koprodukcji przejmowała jugosłowiańska służba bezpieczeństwa, aby finansować tajne operacje za granicą. Zob. P. Stankovič, A Small Cinema from the other Side of the Alps: A Historical Overview of Slovenian Films, „Film History” 2012, t. 24, s. 35-55, s. 42.

${ }^{17}$ Viba Film wyprodukował 92 filmy: 61 samodzielnie, a 31 we współpracy z innymi partnerami słoweńskimi i jugosłowiańskimi, https://www.vibafilm.si/o-nas/zgodovina (dostęp: 15.04.2019).

${ }^{18}$ M. Rau-Selič, dz. cyt.

${ }^{19}$ Czerwone klasy (Rdečje klasje, 1970) Živojina Pavloviča, Oxygen (1970) Matjaža Klopčiča, Poza (Onkraj, 1970) Jože Galeta, Ostatnia stacja (Poslednja postaja, 1971) Jože Babiča czy Uciekinier (Begunec, 1973) Jane Kavčiča. Przemysł filmowy w Jugosławii był mocno zintegrowany, zespoły były często międzynarodowe, a twórcy kręcili filmy w całym kraju. Umożliwiała to tzw. polityka braterstwa i jedności mająca na celu stworzenie nowej tożsamości jugosłowiańskiej w miejsce podziałów narodowych. Wszyscy robili wszystko, aby Jugosławia została zauważona, żeby stała się filmem: założono Miasto Filmowe, przerobiono Jugosławie $w$ gigantyczne studio filmowe o wielu lokalizacjach, fabryki finansowaty produkcje filmowe, Tito tak modyfikowat scenariusze, aby byly ,,prawdziwsze” (,, To nie wyglądało tak”, ,Nie trzeba mnie pokazywać w tym filmie", itd.), żotnierze Jugosłowiańskiej Armii Ludowej grali Niemców, a pozostali Jugostowianie Indian, Egipcjan, wikingów i Persów. Oczywiście podczas kręcenia ,Bitwy nad Neretwa", do której plakat wykonat Picasso, nie wysadzono makiety, ale prawdziwy most, który taczyt oba brzegi rzeki. Wszystko dla filmu! M. Štefančič Jr., Maškarada. Strašne fantazije slovenskega filma (1948-1990), Ljubljana 2013, s. 672. 


\section{PERTURBACJE KINEMATOGRAFII SŁOWEŃSKIEJ}

${ }^{20}$ Wszędzie zaostrzała się cenzura. W latach 70 . nasiliły się nastroje rozrachunkowe, rozliczano się z nacjonalizmem i liberalizmem: Niezwykła kombinacja zaostrzonej dyktatury partyjnej (lata 70. określa się mianem ,ołowianych lat”) i wzmocnionej autonomii republik, która nastapiła po rozrachunku z liberalizmem, była po prostu kompromisem, poprzez który ówczesna władza próbowała zachować narodowa i kulturową skrajnie różnorodna Jugosławię przy życiu. P. Stankovič, Zgodovina slovenskega celovečernega igranega filma. Slovenski klasični film (1931-1988), Ljubljana 2013, s. 342.

${ }^{21}$ Trzeba tu wymienić Maskaradę (Maškarada, 1971) Boštjana Hladnika - reżyser już na etapie scenariusza wiedział, że z powodu scen erotycznych i pornograficznych nie otrzyma pozwolenia na realizację filmu i przekazał oryginał scenariusza tylko wąskiemu gronu ekipy filmowej. Jak twierdzi Štefančič Jr., jeszcze nigdy nie byto tyle seksu $w$ kinie stoweńskim i że podczas kręcenia wszyscy byli nadzy lub pótnadzy - nie ubierali się nawet podczas przerw. Spokojnie grali w karty (M. Štefančič Jr., Na svoji zemlji... dz. cyt., s. 99). Oczywiście Viba Film zażądał modyfikacji filmu, ostatecznie sam go przerobił, a reżyser nie pojawił się na premierze, a następnie wyemigrował. Oryginalna wersja ukazała się dopiero w 1982 r., i to tylko w kinach typu Sloga, gdzie pokazywano filmy erotyczne i pornograficzne. Więcej o kinie Sloga w: Retroseks. Nekoč v Slogi, pod red. M. Peče, Ljubljana 2014.

${ }^{22}$ P. Stankovič, dz. cyt., s. 533.

${ }^{23}$ Zob. T. N. Kocjančič, F. Robar Dorin, Dialogi s Filipom, Lublana 2017, s. 51.

${ }^{24}$ P. Stankovič, dz. cyt., s. 510.

${ }^{25}$ Tamże.

${ }^{26}$ Decydujacy telefon został zrealizowany przy wsparciu Studenckiego Centrum Kulturalnego (ŠKUC) w Lublanie. ŠKUC przez ponad 20 lat wspierał $\mathrm{i}$ inspirował wszystkie formy aktywności producenckich i filmowych, które były marginalizowane przez biurokrację oficjalnej kultury socjalistycznej, https://monoskop.org/Slovenia\#Centres (dostęp: 18.04. 2019). W 1991 r. powstała niezależna firma producencka - E-motion Film - która była jedną z pierwszych w Słowenii i byłej Jugosławii. Wyprodukowała ona ponad 30 filmów. W 1994 r. producent Hočevar, reżyser Kozole i Metod Pevec założyli Vertigo, które wyprodukowało ponad 40 filmów i koprodukcji międzynarodowych. Za film, który odniósł największy sukces, uchodzi Na luzie Janeza Burgera - zdobywca ponad 20 nagród.
${ }^{27}$ Z. Vrdlovec, Zgodovina filma na Slovenskem 1896-2011, Ljubljana 2013, s. 658.

${ }^{28}$ Tamże, s. 670.

29 Tamże, s. 713.

${ }^{30} \mathrm{~S}$. Šimenc, Panorama slovenskega filma, Ljubljana 1996, s. 86.

${ }^{31}$ Słoweńska Kinoteka w Lublanie to do dziś jeden z najważniejszych ośrodków kultury filmowej. Pracuje nad retrospektywami, publikacjami, wydarzeniami, http://www.kinoteka.si/si/504/programski_oddelek.aspx (dostęp: 15.04.2019).

${ }^{32}$ A. Šprah, Osvobajanje pogleda. Eseji o sodobnem slovenskem filmu, Ljubljana 2004, s. 10 .

${ }^{33}$ Vesna (wiosna) to przedsiębiorstwo dystrybucyjne z czasów Jugosławii; to także tytuł hitu kinowego Františka Čápa (1953) oraz najwyższa nagroda w dziedzinie sztuki filmowej na Festiwalu Filmu Słoweńskiego.

${ }^{34}$ Z. Vrdlovec, dz. cyt., s. 653.

35 Tamże, s. 735.

${ }^{36}$ Słoweńskimi koproducentami byli: Fundusz Filmowy, Casablanca i Maj. W produkcji brali udział słoweńscy aktorzy, np. Tanja Ribič, Aleš Valič, Uroš Furst, scenograf Duško Milavec, organizator zdjęć Tomaž Lehpamer i inni pracownicy filmowi. (Zob. M. Štefančic Jr., Na svoji zemlji... dz. cyt., s. 192). Od 2000 r., wraz z początkiem wspierania koprodukcji międzynarodowych, Fundusz Filmowy współfinansował ponad 30 filmów pełnometrażowych, w które koproducenci słoweńscy wnosili mniejszy wkład. Powstały takie filmy jak: Szara ciężarówka w kolorze czerwonym (Sivi kamion crvene boje, reż. Srđjan Koljević, 2004), Posterunek graniczny (Karaula, reż. Rajko Grlić, 2006), Parada (reż. Srđjan Dragojević, 2011), Konstytucja (Ustava republike Hrvaške, reż. Rajko Grlić, 2017), Faceci nie płacza (Muškarci ne plaču, reż. Alen Drljević, 2017) czy Bóg istnieje i nazywa się Petrunja (Gospod postoi, imeto i e Petrunja, reż. Teona Mitevska, 2019). Zob. Filmski center, https://www.film-center.si/sl/film-vsloveniji/filmska-produkcija/ (dostęp: 16.04.2019).

${ }^{37} \mathrm{~J}$. Meden, O kruhu in mleku (wywiad z Janem Cvitkoviciem, „Ekran” 2001, t. XXXVIII, nr 3/4, s. 6-9.

${ }^{38}$ Cvitkovič o družini pred težko preizkušnjo in moči njenih, wywiad z Janem Cvitkoviciem, https://www.rtvslo.si/kultura/film-in-tv/cvitkovic-o-druzini-pred-tezko-preizkusnjo-in-mocinjenih-povezav/434914 (dostęp: 15.04.2019).

${ }^{39}$ Maja Weiss poza filmem fabularnym Instalacja miłości (Instalacija ljubezni, 2007) zrealizo- 


\section{MAŠA GUŠTIN}

wała też kilka dokumentów: Odkrywanie ukrytego wspomnienia Ageli Vode (Odkrivanje skritega spomina Angele Vode, 2011), Oczy i uszy Boga (Oči in ušesa boga, 2012) czy Banditenkinder - dzieci skradzione słoweńskiemu narodowi (Banditenkinder - slovenskemu narodu ukradeni otroci, 2014).

${ }^{40}$ Wojcik-Slak była reżyserką bądź współpracowała przy realizacji takich filmów, jak np. Desperado tonic (reż. Hanna-Antonina Wojcik-Slak, Boris Petkovič, Varja Močnik, Zoran Živulović, 2004), Kilka innych historii (Neke druge zgodbe, reż. Hanna Antonina Wojcik-Slak, Ivona Juka, Ana Maria Rossi, Ines Tanović, Marja Džidževa, 2010) i Górnik (Rudar, reż. Hanna-Antonina Wojcik-Slak, 2016).

${ }^{41}$ M. Valentinčič, Varuh meje, „Ekran”, XXXIX r., t. 27, nr 3-4, s. 9.

${ }^{42}$ M. Štefančič Jr, Slovenski film 2.0. Kritična enciklopedija slovesnkega celovečernega filma 1991-2016, Ljubljana 2016, s. 36.

${ }^{43}$ Głównym inwestorem było państwo, a konkretnie Ministerstwo Kultury. Zob. Z. Vrdlovec, Zgodovina filma... dz. cyt., s. 741.

${ }^{44}$ Mitja Okorn jest prawdopodobnie jedynym znanym w Polsce reżyserem słoweńskim. Nakręcił tu komedie romantyczne Listy do $M$. (2011) oraz Planetę Singli (2016).

${ }^{45}$ Dvakrat odbiti ,Tu in tam”, https://www.24ur.com/dvakrat-odbiti-tu-pa-tam.html (dostęp: 16.04.2019).

${ }^{46} \mathrm{Z}$. Vrdlovec, Zgodovina filma... dz. cyt., s. 782.

${ }^{47}$ Tamże, s. 782.

${ }^{48}$ Słoweńscy producenci poza wsparciem Centrum Filmowego mogą liczyć na subwencje europejskiego programu MEDIA Desk oraz funduszu europejskiego Eurimages. Zob. Sło- weńskie Centrum Filmowe, https://www.filmcenter.si/sl/o-centru/ (dostęp: 16.04.2019).

${ }^{49} \mathrm{Z}$. Vrdlovec, Filmski ravs med politiko in stroke, „Dnevnik”, 29.05.2010, https://www.dnevnik.si/1042363040 (dostęp: 16.04.2019).

${ }^{50}$ Słoweńskie Centrum Filmowe, https://www.film-center.si/sl/o-centru/ (dostęp: 15.04.2019).

${ }^{51}$ Tamże.

${ }^{52}$ Więcej na temat komunikatu Centrum na stronie, .pdf(dostęp: 15.04.2019). Informacje dotyczące statystyk Centrum można znaleźć na stronie https://www.film-center.si/sl/film-v-sloveniji/filmska-produkcija/ (dostęp: 16.04.2019).

${ }^{53}$ Vojnović, nie otrzymawszy dofinansowania od Funduszu Filmowego na film Czefurzy raus!, przerobił scenariusz na książkę, która w $2008 \mathrm{r}$. została wydana w wydawnictwie Študentska založba w Lublanie. Opowieść o drugim pokoleniu imigrantów z byłych republik Jugosławii, nazywanych pogardliwie czefurami, zdobyła najważniejsze nagrody literackie w Stowenii (...), wywowała skandal polityczny, osiagneła najlepszy wynik sprzedaży $w$ roku 2009, a na jej podstawie napisano sztukę teatralna bijąca rekordy popularności. M. Guštin, T. Łukaszewicz, Wstęp, w: G. Vojnović, Czefurzy raus!, tłum. T. Łukaszewicz, Gdańsk 2010, s. 5. Vojnović przyznał, że sukces książki zdecydowanie pomógł mu w karierze (skończył studia reżyserskie w Lublanie), dostał subwencję na debiut pełnometrażowy Piran Pirano, a później także na film Czefurzy raus! Zob. M. Guštin, Wywiad z Goranem Vojnoviciem, w: G. Vojnović, dz. cyt., s. 204-212.

${ }^{54}$ P. Levi, Razpad Jugoslavije na filmu, Ljubljana 2011, s. 136. 